\title{
THE ABSORPTION 'AND EXCRETION OF STREPTOMYCIN IN HUMAN CHRONIC TYPHOID CARRIERS
}

\author{
By DAVID D. RUTSTEIN, ROBERT B. STEBBINS, RICHARD T. CATHCART, \\ AND REJANE M. HARVEY \\ (From the First (Columbia) Medical Division, Bellevue Hospital, New York City, \\ Merck Institute for Therapeutic Research, Rahway, New Jersey, \\ and the Department of Health of the City of New York)
}

(Received for publication on August 17, 1945)

Streptomycin, ${ }^{1}$ an antibiotic agent produced by the growth of Actinomyces griseus, has been shown to inhibit the growth of gram negative bacilli both in vitro ( 1 to 5 ) and in animals (2, 3, 6 to 9$)$. Preliminary data on the absorption and excretion of this drug were obtained in a patient suffering from acute bacterial endocarditis due to Pseudomonas aeruginosa, the first human patient treated with streptomycin (10). The data indicated that it was possible to attain levels of the drug in the blood in the range of sensitivity of gram-negative bacilli of this antibiotic agent and justified the performance of more detailed studies of absorption and excretion of streptomycin.

Chronic typhoid carriers were selected as subjects for this study for several reasons; they were as relatively "normal" individuals as could be found in the population of the hospital and, in addition, provided an opportunity to study the effect of streptomycin on the typhoid carrier state.

\section{METHOD OF STUDY}

Four male chronic typhoid carriers, under the jurisdiction of the Department of Health of the City of New York, were admitted to the First Medical Division of Bellevue Hospital. These individuals were known to have had consistently positive cultures of typhoid bacilli in their stools without exception for at least 2 years. Following admission, a medical history was obtained and a physical examination was performed. The following control measurements in relation to this study were made: complete blood count, urinalysis, erythrocyte sedimentation rate (Westegren method), blood urea nitrogen (11), cephalin flocculation test (12), icteric index, and electrocardiogram. In addition to the tests performed in relation to drug absorption and excretion, the following measurements were made in relation to the typhoid carrier state. These included urine and stool cultures on MacConkey medium, Bacto S. S. Agar, and Wilson-Blair medium. The typhoid bacilli were typed according to the

1 The streptomycin used in this study was supplied by Merck and Co., Inc., and consisted of lots numbered 4R6040 and 4R6223. bacteriophage method of Craigie and Yen (13). The urine cultures were performed prior to therapy and repeated twice on successive days. Stool cultures were performed prior to therapy and daily thereafter, the last specimen being taken 15 hours after therapy was discontinued. The sensitivity of the strains of typhoid bacilli were determined by the agar plate method.

An intracutaneous skin test on the flexor aspect of the right forearm was performed with $0.1 \mathrm{ml}$. of $1: 10$ dilution of streptomycin. Twenty minutes later the tests were read and no reactions were noted.

Prior to the administration of the drug the patients were instructed to empty their bladders. A specimen of the urine was taken for urinalysis, the remainder being discarded. Thereafter, for the duration of the study, a record was kept of the intake and output of fluids in each patient.

A dose of 75,000 units of streptomycin in $5 \mathrm{ml}$. of solution was then injected intramuscularly. The time periods indicated in all the tables of this study denote the time elapsed following the first injection. The hour when the first injection was made is considered as the zero hour in the study. One hour later a blood specimen was taken for a determination of the concentration of streptomycin. The subjects were instructed to empty their bladders, the volume of urine was measured and recorded, and a specimen of the urine was taken for streptomycin assay. Similar specimens were taken and measurements made at the end of the second and third hours after the first injection. At this latter time, the patients received another 75,000 units of streptomycin intramuscularly, blood and urine specimens being collected before the injections were given. Thereafter, during this phase of the study, each patient received 75,000 units of streptomycin intramuscularly every 3 hours until a total of 600,000 units had been given in 8 injections.

The concentration of streptomycin in the blood and urine specimens are indicated in Tables I to IV. When the time of injection coincided with the time of the taking of the specimen, samples were obtained before the injections were given.

Twenty-four hours after the onset of the study, the dose of streptomycin was increased to 150,000 units in $10 \mathrm{ml}$. of solution intramuscularly every 3 hours. At this dosage level a total of 1,950,000 units of streptomycin were given in 13 injections from the twenty-fifth to the sixtieth hour of the study.

Beginning at the sixty-third hour, the dosage was reduced to the original level of 75,000 units in $5 \mathrm{ml}$. intra- 
TABLE I

Blood and urine concentration and excretion of streptomycin in relation to dosage by time periods Subject-Nadherny

\begin{tabular}{|c|c|c|c|c|c|}
\hline Time period & Urine output & Dosage & $\begin{array}{c}\text { Blood } \\
\text { concentration }\end{array}$ & $\begin{array}{c}\text { Urine } \\
\text { concentration }\end{array}$ & Excretion \\
\hline $\begin{array}{l}\text { hour } \dagger \\
\text { Control } \\
1 \\
2 \\
3 \\
12 \\
24\end{array}$ & $\begin{array}{r}m l . \\
375 \\
100 \\
100 \\
1,125 \\
1,890\end{array}$ & units per 3, hours & $\begin{array}{l}u n i t \\
1.0 \text { to } 2.0 \\
1.0 \text { to } 2.0 \\
1.0 \text { to } 2.0 \\
1.0 \text { to } 2.0 \\
1.0 \text { to } 2.5 \\
1.0 \text { to } 2.0\end{array}$ & $\begin{array}{r}40.0 \\
80.0 \\
80.0 \\
80.0 \\
140.0\end{array}$ & $\begin{array}{r}\text { units } \\
\\
15,000 \\
8,000 \\
8,000 \\
90,000 \\
264,000\end{array}$ \\
\hline $\begin{array}{l}25 \\
26 \\
27 \\
36 \\
37 \\
38 \\
39 \\
39 \mathrm{~b} \\
48 \\
60\end{array}$ & $\begin{array}{r}200 \\
450 \\
800 \\
200 \\
250 \\
150 \\
600 \\
1,790 \\
1,375 \\
\end{array}$ & 150,000 intramuscularly for 13 doses & $\begin{array}{r}8.0 \\
13.0 \\
6.0 \\
13.0 \\
\\
18.0 \\
10.0 \\
8.0\end{array}$ & $\begin{array}{l}160.0 \\
140.0 \\
400.0 \\
400.0 \\
200.0 \\
\\
240.0 \\
180.0 \\
270.0\end{array}$ & $\begin{array}{r}32,000 \\
63,000 \\
320,000 \\
80,000^{*} \\
50,000^{*} \\
144,000 \\
322,000 \\
371,000\end{array}$ \\
\hline $\begin{array}{l}63 \\
66\end{array}$ & & 75,000 intramuscularly for 2 doses & & & \\
\hline $\begin{array}{l}69 \\
72 \\
84 \\
93\end{array}$ & $\begin{array}{r}3,975 \\
1,410 \\
600\end{array}$ & None & $\begin{array}{l}5.0 \\
1.0 \text { to } 2.5 \\
1.0 \text { to } 2.5\end{array}$ & $\begin{array}{l}70.0 \\
40.0 \\
20.0\end{array}$ & $\begin{array}{r}278,250 \\
56,400 \\
12,000\end{array}$ \\
\hline $\begin{array}{r}94 \\
95 \\
96 \\
97 \\
109 \\
117\end{array}$ & $\begin{array}{r}600 \\
800 \\
700 \\
500 \\
1,750 \\
1,340\end{array}$ & 31,250 orally** for 8 doses & $\begin{array}{l}1.0 \text { to } 2.5 \\
1.0 \text { to } 2.5 \\
1.0 \text { to } 2.5 \\
1.0 \text { to } 2.5 \\
1.0 \text { to } 2.5 \\
1.0 \text { to } 2.5\end{array}$ & $\begin{array}{r}2.5 \\
0 \\
2.5 \\
2.5 \\
2.5 \\
2.5\end{array}$ & $\begin{array}{r}1,500 \\
0 \\
1,750 \\
1,250 \\
4,375 \\
3,350\end{array}$ \\
\hline $\begin{array}{l}120 \\
132\end{array}$ & $\begin{array}{r}800 \\
2,150\end{array}$ & None & $\begin{array}{c}1.0 \text { to } 2.5 \\
1.25\end{array}$ & $\begin{array}{r}0 \\
2.5\end{array}$ & $\begin{array}{r}0 \\
5,375\end{array}$ \\
\hline
\end{tabular}

* These 2 excretion values are not included in the total excretion because sample $39 \mathrm{~b}$ includes the total excretion during hours 37 to 39 ( 881,200 units).

** Blood levels following oral administration reported on a basis of estimated unitage.

$\uparrow$ Hour at which blood was taken.

muscularly for 2 doses. Intramuscular administration was then discontinued. These latter changes in dosage were made necessary by the toxic manifestations of the particular lot of drug studied.

From the sixty-ninth through the ninety-third hour, no further drug was administered but specimens of blood and urine were collected as indicated in Tables I to IV.

Beginning at the ninety-fourth hour and ending at the one hundred seventeenth hour, 31,250 units per dose of streptomycin were administered orally in capsules for 8 doses.

From the one hundred twentieth to the one hundred thirty-second hour, no further drug was administered but specimens were again collected as indicated in Tables I to IV.

Each day during the course of the study the following measurements were made on each patient: fluid intake and urinary output, urinalysis, complete blood count, blood urea nitrogen, erythrocyte sedimentation rate, blood pressure, and electrocardiogram. Temperature, pulse, and respiration were recorded every 4 hours throughout the day and night. An icteric index and a cephalin flocculation test were repeated at the end of the study.

\section{Procedure for the assay of streptomycin in blood and urine ${ }^{2}$}

The concentrations of streptomycin in the blood and urine were determined by a modification of

2 The assay method used in this study was devised by one co-author (R. B. S.) in cooperation with Dr. H. J. Robinson. This method making use of $B$. subtilis as the test organism should not be confused with the more recently developed assay employing Staphylococcus aureus SM. (15), the latter method being more accurate than the present method which is not precise enough for levels below 5 units per $\mathrm{ml}$. All levels below 5 units per $\mathrm{ml}$. in this paper are estimates and are not to be considered as definite levels. 
TABLE II

Blood and urine concentration and excretion of streptomycin in relation to dosage by time periods Subject-Russo

\begin{tabular}{|c|c|c|c|c|c|}
\hline $\begin{array}{c}\text { Time } \\
\text { period }\end{array}$ & $\begin{array}{l}\text { Urine } \\
\text { output }\end{array}$ & Dosage & $\begin{array}{c}\text { Blood } \\
\text { concentration }\end{array}$ & $\begin{array}{c}\text { Urine } \\
\text { concentration }\end{array}$ & Excretion \\
\hline $\begin{array}{c}\text { hour } \dagger \\
\text { Control } \\
1 \\
2 \\
3 \\
12 \\
24\end{array}$ & $\begin{array}{r}m l . \\
350 \\
650 \\
300 \\
675 \\
2,765\end{array}$ & $\begin{array}{l}\text { units per } 3 \text { hrs. } \\
75,000 \text { intramuscularly for } \\
8 \text { doses }\end{array}$ & $\begin{array}{l}\text { unit } \\
1.0 \text { to } 2.0 \\
1.0 \text { to } 2.0 \\
1,0 \text { to } 2.0 \\
1.0 \text { to } 2.0 \\
2.5 \text { to } 5.0 \\
6.0\end{array}$ & $\begin{array}{r}m l . \\
\\
20.0 \\
20.0 \\
40.0 \\
100.0 \\
100.0\end{array}$ & $\begin{array}{r}\text { units } \\
7,000 \\
13,000 \\
12,000 \\
67,500 \\
276,500\end{array}$ \\
\hline $\begin{array}{l}25 \\
26 \\
27 \\
36 \\
37 \\
38 \\
39 \\
39 \mathrm{~b} \\
48 \\
60\end{array}$ & $\begin{array}{r}725 \\
450 \\
550 \\
525 \\
400 \\
925 \\
2,670 \\
1,725\end{array}$ & $\begin{array}{l}150,000 \text { intramuscularly for } \\
13 \text { doses }\end{array}$ & $\begin{array}{r}18.0 \\
13.0 \\
8.0 \\
20.0 \\
\\
\\
20.0 \\
\\
20.0 \\
20.0\end{array}$ & $\begin{array}{r}60.0 \\
80.0 \\
270.0 \\
240.0 \\
\\
150.0 \\
180.0 \\
240.0\end{array}$ & $\begin{array}{r}43,500 \\
36,000 \\
148,500 \\
126,000^{*} \\
138,750 \\
480,600 \\
414,000\end{array}$ \\
\hline $\begin{array}{l}63 \\
66\end{array}$ & & $\begin{array}{l}75,000 \text { intramuscularly for } \\
2 \text { doses }\end{array}$ & & & \\
\hline $\begin{array}{l}69 \\
72 \\
84 \\
93\end{array}$ & $\begin{array}{l}3,475 \\
3,350 \\
2,580\end{array}$ & None & $\begin{array}{l}15.0 \\
5.0 \\
1.25\end{array}$ & $\begin{array}{r}80.0 \\
20.0 \\
5.0\end{array}$ & $\begin{array}{r}278,000 \\
67,000 \\
12,900\end{array}$ \\
\hline $\begin{array}{r}94 \\
95 \\
96 \\
97 \\
109 \\
117\end{array}$ & $\begin{array}{r}600 \\
650 \\
700 \\
500 \\
2,600 \\
2,190\end{array}$ & 31,250 orally** for 8 doses & $\begin{array}{l}1.0 \text { to } 2.5 \\
1.0 \text { to } 2.5 \\
1.0 \text { to } 2.5 \\
1.0 \text { to } 2.5 \\
1.0 \text { to } 2.5 \\
1.0 \text { to } 2.5\end{array}$ & $\begin{array}{l}5.0 \\
3.0 \\
5.0 \\
3.0 \\
3.0 \\
3.0\end{array}$ & $\begin{array}{l}3,000 \\
1,950 \\
3,500 \\
1,500 \\
7,800 \\
6,570\end{array}$ \\
\hline $\begin{array}{l}120 \\
132\end{array}$ & $\begin{array}{l}1,250 \\
1,220\end{array}$ & None & $\begin{array}{l}<1.25 \\
<1.25\end{array}$ & $\begin{array}{l}3.0 \\
8.0\end{array}$ & $\begin{array}{l}3,750 \\
9,760\end{array}$ \\
\hline
\end{tabular}

* This excretion value is not included in the total excretion because sample $39 \mathrm{~b}$ includes the total excretion during hours 37 to $39(138,750$ units).

** Blood levels following oral administration reported on a basis of estimated unitage.

$\dagger$ Hour at which blood was taken.

the Foster-Woodruff assay method (14) for streptothricin. In order to increase the sensitivity of the method, all blood samples were hemolyzed by the addition of weighed amounts ( 0.5 to 1.0 mgm.) of saponin. This prevented the red cells in the blood samples from settling at the base of the penicylinders, thereby facilitating diffusion of the drug through the agar.

The concentration of streptomycin in blood was determined from a standard curve of reference for each blood assay. Dilutions of the drug standard $(5,10,20,40,60,80,100$ units per ml.) were made in normal hemolyzed blood, with the latter as diluent. The diameters of the resulting zones of cleared area were plotted as ordinates against the concentrations of streptomycin as abcissae.
Test bloods were diluted when necessary with normal hemolyzed blood to contain approximately 20 to 60 units per $\mathrm{ml}$., otherwise the sample was assayed undiluted. Dilutions of the test sample and each standard level were run in duplicate. The concentration of streptomycin in a test sample was obtained by determining from the standard curve the drug concentration corresponding to the diameter of the zone of inhibition and correcting for the dilution.

Distilled water replaced whole hemolyzed blood as the diluent in the assay of the urine specimens.

In the preparation of agar plates for the assay, $0.1 \mathrm{ml}$. of a standardized $B$. subtilis ${ }^{3}$ inoculum was added to each $100 \mathrm{ml}$. of molten (45 to $50^{\circ} \mathrm{C}$.)

\footnotetext{
${ }^{3}$ Supplied by Microbiological Laboratories, Merck \& Co., Inc.
} 
F.D.A. agar. By means of a calibrated wide mouth pipette, $13 \mathrm{ml}$. of the seeded agar was delivered into each petri dish. After cooling and solidification of the agar, beveled glass penicylinders were warmed in a Bunsen flame and placed upon the agar surface resulting in an effective seal between the glass cylinder and the agar. The cylinders were then filled with the test samples. For the assay of blood specimens both the standard and the test samples were placed in the icebox overnight to insure complete diffusion of the drug through the agar plate but this was not necessary in the case of urine specimens. The plates were then incubated at $30^{\circ} \mathrm{C}$. for 16 to 18 hours. The diameters of the cleared areas were then recorded in millimeters.

\section{Absorption and excretion of streptomycin}

Individual observations at various time periods in urine output, blood concentration, urine concentration and excretion of streptomycin in the 4 subjects studied are detailed in Tables I to IV. In these tables it will be noted that the concentration of streptomycin in the blood resulting from a dose of 75,000 units intramuscularly every 3 hours are very low and are at the same level as the control blood specimens. They are also in approximately the same range obtainable as a result of oral administration of 31,250 units every 3 hours. These levels are so low that they cannot accurately be determined by the method used, but it is obvious that they are below the expected range of therapeutic effectiveness of the drug against most of

TABLE III

Blood and urine concentration and excretion of streptomycin in relation to dosage by time periods Subject-Schwaid

\begin{tabular}{|c|c|c|c|c|c|}
\hline $\begin{array}{l}\text { Time } \\
\text { period }\end{array}$ & $\begin{array}{c}\text { Urine } \\
\text { output }\end{array}$ & Dosage & $\underset{\text { Blood }}{\text { concentration }}$ & $\begin{array}{c}\text { Urine } \\
\text { concentration }\end{array}$ & Excretion \\
\hline 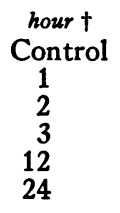 & $\begin{array}{r}m l . \\
500 \\
350 \\
400 \\
1,325 \\
2,540\end{array}$ & $\begin{array}{l}\text { units per } 3 \text { hrs. } \\
75,000 \text { intramuscularly for } \\
8 \text { doses }\end{array}$ & $\begin{array}{l}1.0 \text { to } 2.0 \\
2.5 \\
1.0 \text { to } 2.0 \\
1.0 \text { to } 2.0 \\
2.5 \text { to } 5.0 \\
2.5\end{array}$ & $\begin{array}{r}20.0 \\
70.0 \\
80.0 \\
100.0 \\
100.0\end{array}$ & $\begin{array}{c}\text { units } \\
\\
10,000 \\
24,500 \\
32,000 \\
132,500 \\
254,000\end{array}$ \\
\hline $\begin{array}{l}25 \\
26 \\
27 \\
36 \\
37 \\
38 \\
39 \\
39 \mathrm{~b} \\
48 \\
60\end{array}$ & $\begin{array}{r}150 \\
175 \\
640 \\
\\
125 \\
200 \\
325 \\
1,615 \\
450\end{array}$ & $\begin{array}{l}150,000 \text { intramuscularly for } \\
13 \text { doses }\end{array}$ & $\begin{array}{r}18.0 \\
20.0 \\
18.0 \\
13.0 \\
\\
18.0 \\
\\
8.0 \\
10.0\end{array}$ & $\begin{array}{l}140.0 \\
100.0 \\
320.0 \\
\\
320.0 \\
\\
200.0 \\
200.0 \\
400.0\end{array}$ & $\begin{array}{r}21,000 \\
17,500 \\
204,000 \\
40,000^{*} \\
65,000 \\
323,000 \\
180,000\end{array}$ \\
\hline $\begin{array}{l}63 \\
66\end{array}$ & & $\begin{array}{l}75,000 \text { intramuscularly for } \\
2 \text { doses }\end{array}$ & & & \\
\hline $\begin{array}{l}69 \\
72 \\
.84 \\
93\end{array}$ & $\begin{array}{l}1,075 \\
1,825 \\
1,400\end{array}$ & None & $\begin{array}{l}8.0 \\
5.0 \\
2.5\end{array}$ & $\begin{array}{l}60.0 \\
90.0 \\
15.0\end{array}$ & $\begin{array}{r}64,500 \\
164,250 \\
21,000\end{array}$ \\
\hline $\begin{array}{r}94 \\
95 \\
96 \\
97 \\
109 \\
117\end{array}$ & $\begin{array}{r}700 \\
300 \\
200 \\
200 \\
1,750 \\
1,490\end{array}$ & 31,250 orally** for 8 doses $^{* *}$ & $\begin{array}{l}1.0 \text { to } 2.5 \\
1.0 \text { to } 2.5 \\
1.0 \text { to } 2.5 \\
1.0 \text { to } 2.5 \\
2.5 \\
2.5 \text { to } 5.0\end{array}$ & $\begin{array}{r}8.0 \\
20.0 \\
10.0 \\
10.0 \\
5.0 \\
5.0\end{array}$ & $\begin{array}{l}5,600 \\
6,000 \\
2,000 \\
2,000 \\
8,750 \\
7,450\end{array}$ \\
\hline $\begin{array}{l}120 \\
132\end{array}$ & $\begin{array}{l}250 \\
740\end{array}$ & None & $\begin{array}{l}1.25 \text { to } 2.5 \\
<1.25\end{array}$ & $\begin{array}{r}8.0 \\
15.0\end{array}$ & $\begin{array}{r}2,000 \\
11,100\end{array}$ \\
\hline
\end{tabular}

* This excretion value is not included in the total excretion because sample $39 \mathrm{~b}$ includes the total excretion during hours 37 to 39 (631,000 units).

** Blood levels following oral administration reported on a basis of estimated unitage.

† Hour at which blood was taken. 
TABLE IV

Blood and urine concentration and excretion of streptomycin in relation to dosage by time periods Subject-Weiss

\begin{tabular}{|c|c|c|c|c|c|}
\hline $\begin{array}{l}\text { Time } \\
\text { period }\end{array}$ & $\begin{array}{l}\text { Urine } \\
\text { output }\end{array}$ & Dosage & $\begin{array}{c}\text { Blood } \\
\text { concentration }\end{array}$ & $\begin{array}{c}\text { Urine } \\
\text { concentration }\end{array}$ & \multirow{2}{*}{$\begin{array}{r}\text { Excretion } \\
\text { units } \\
6,500 \\
11,250 \\
14,000 \\
66,000 \\
175,600\end{array}$} \\
\hline $\begin{array}{l}\text { hour } t \\
\text { Control } \\
1 \\
2 \\
3 \\
12 \\
24\end{array}$ & $\begin{array}{r}m l . \\
\\
325 \\
75 \\
200 \\
660 \\
2,195\end{array}$ & $\begin{array}{l}\text { units per } 3 \text { hrs. } \\
75,000 \text { intramuscularly for } \\
8 \text { doses }\end{array}$ & \multicolumn{2}{|c|}{\begin{tabular}{l|r} 
units per ml. \\
.0 & \\
.0 & \\
.0 & 20.0 \\
.0 & 150.0 \\
.0 & 70.0 \\
& 100.0 \\
& 80.0
\end{tabular}} & \\
\hline 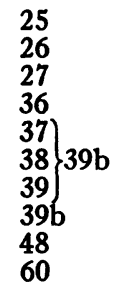 & $\begin{array}{r}300 \\
400 \\
500 \\
50 \\
225 \\
350 \\
625 \\
2,015 \\
355\end{array}$ & $\begin{array}{l}150,000 \text { intramuscularly for } \\
13 \text { doses }\end{array}$ & $\begin{array}{r}5.0 \\
13.0 \\
10.0 \\
8.0 \\
\\
13.0 \\
10.0 \\
6.0\end{array}$ & $\begin{array}{r}40.0 \\
80.0 \\
280.0 \\
400.0 \\
120.0 \\
\\
120.0 \\
200.0 \\
200.0\end{array}$ & $\begin{array}{r}12,000 \\
32,000 \\
140,000 \\
20,000^{*} \\
27,000^{*} \\
75,000 \\
403,000 \\
71,000\end{array}$ \\
\hline $\begin{array}{l}63 \\
66\end{array}$ & & $\begin{array}{l}75,000 \text { intramuscularly for } \\
2 \text { doses }\end{array}$ & & & \\
\hline $\begin{array}{l}69 \\
72 \\
84 \\
93\end{array}$ & $\begin{array}{l}2,695 \\
2,125 \\
1,500\end{array}$ & None & $\begin{array}{l}5.0 \\
1.25 \\
2.5\end{array}$ & $\begin{array}{l}70.0 \\
20.0 \\
10.0\end{array}$ & $\begin{array}{r}188,650 \\
42,500 \\
15,000\end{array}$ \\
\hline $\begin{array}{r}94 \\
95 \\
96 \\
97 \\
109 \\
117\end{array}$ & $\begin{array}{r}700 \\
400 \\
400 \\
350 \\
1,250 \\
1,660\end{array}$ & 31,250 orally** for 8 doses & $\begin{array}{l}1.25 \\
1.25 \\
1.0 \text { to } 2.5 \\
1.0 \text { to } 2.5 \\
1.0 \text { to } 2.5 \\
1.0 \text { to } 2.5\end{array}$ & $\begin{array}{l}0.0 \\
2.5 \\
2.5 \\
2.5 \\
2.5 \\
0.0\end{array}$ & $\begin{array}{r}0 \\
1,000 \\
1,000 \\
875 \\
3,125 \\
0\end{array}$ \\
\hline $\begin{array}{l}120 \\
132\end{array}$ & $\begin{array}{l}650 \\
490\end{array}$ & None & $\begin{array}{l}1.0 \text { to } 2.5 \\
<1.25\end{array}$ & $\begin{array}{l}0.0 \\
2.5\end{array}$ & $\begin{array}{r}0 \\
1,225\end{array}$ \\
\hline
\end{tabular}

* These 2 excretion values are not included in the total excretion because sample $39 \mathrm{~b}$ includes the total excretion during hours 37 to 39 (75,000 units).

* Blood levels following oral administration reported on the basis of estimated unitage.

t Hour at which blood was taken.

the microorganisms which have thus far been tested in vitro (3). However, the number of units excreted in the interval during intramuscular administration of 75,000 units every 3 hours is obviously much greater than the amount excreted as a result of the oral administration. This would indicate that very small amounts of the drug are absorbed when administered orally and that when somewhat larger amounts are absorbed, as in the intramuscular dosage of 75,000 units every 3 hours, the drug is excreted in the urine so rapidly that no significant blood level is attained.

In the second phase of the experiment, after increasing the dose to 150,000 units intramuscularly every 3 hours, the concentrations of the drug in the blood rose sharply into the range of thera- peutic effectiveness and were maintained at that level despite excessive intake and output of fluid. Therefore, such levels can reasonably be expected to be attained with this dosage of the drug.

It is further evident from the study of Tables I to IV that even though the dosage of the drug was halved at the sixty-third hour and discontinued at the sixty-sixth hour, a measurable amount of the drug was still present in the blood until the seventy-second hour, and that excretion in the urine continued through the ninety-third hour.

The data in Table $\mathrm{V}$ are summarized in protracted time periods. The percentage excretion of the drug is relatively constant during the first 2 periods regardless of the increase in dosage dur- 
ing the second period. However, during the third period in 2 of the 4 patients ( $S$ and $W$ ), when the urinary output dropped because of the toxic manifestations of the drug, there was a decrease in the output of the drug.

During the fourth period, following discontinuation of the drug administration at which time the output of urine increased in 3 of the 4 patients $(\mathrm{R}, \mathrm{S}$, and $\mathrm{W})$, some of the retained drug was excreted. The small amount of drug absorbed when administered by mouth is reemphasized in Table V.

In Tables VI to IX, pertinent laboratory observations are summarized. This lot of drug produced a leukocytosis with an increase in polymorphonuclear leukocytes, an increase in the sedimentation rate and an increase in the formed elements in the urine. There was a concomitant decrease in the urinary output in 2 patients ( $S$ and $\mathrm{W})$. Examination of the urine approxi-

TABLE V

Dosage, excretion, and cumulative excretion of streptomycin by time periods

\begin{tabular}{|c|c|c|c|c|c|c|}
\hline \multirow{2}{*}{ Time periods } & \multirow{2}{*}{$\begin{array}{c}\text { Streptomycin } \\
\text { Dosage * }\end{array}$} & \multirow{2}{*}{$\begin{array}{c}\text { Fluid } \\
\text { Intake }\end{array}$} & \multirow{2}{*}{ Urine output } & \multicolumn{3}{|c|}{ Streptomycin excretion } \\
\hline & & & & $\begin{array}{l}\text { Amount in } \\
\text { each period }\end{array}$ & $\begin{array}{l}\text { Percentage in } \\
\text { each period }\end{array}$ & $\begin{array}{l}\text { Cumulative } \\
\text { percentage }\end{array}$ \\
\hline \multicolumn{6}{|c|}{ Subject $-N$} & \\
\hline $\begin{array}{c}\text { hours } \\
0 \text { to } 24 \\
25 \text { to } 48 \\
49 \text { to } 72 \\
73 \text { to } 93\end{array}$ & & $\begin{array}{c}m l . \\
7,375 \\
6,640 \\
7,840 \\
3,665\end{array}$ & $\begin{array}{c}m l . \\
3,590 \\
4,140 \\
5,350 \\
2,010\end{array}$ & $\begin{array}{c}\text { units } \\
385,600 \\
881,200 \\
649,500 \\
68,400\end{array}$ & \multirow[t]{2}{*}{$\begin{array}{l}64.3 \\
73.4 \\
72.1\end{array}$} & \multirow{2}{*}{$\begin{array}{l}64.3 \\
70.4 \\
71.0 \\
73.5 \\
67.7 \\
67.9\end{array}$} \\
\hline $\begin{array}{r}94 \text { to } 117 \\
118 \text { to } 132\end{array}$ & & $\begin{array}{l}7,160 \\
2,000\end{array}$ & $\begin{array}{l}5,690 \\
2,950\end{array}$ & $\begin{array}{r}12,225 \\
5,375\end{array}$ & & \\
\hline \multicolumn{7}{|c|}{ Subject- $R$} \\
\hline $\begin{array}{l}\text { hours } \\
0 \text { to } 24 \\
25 \text { to } 48 \\
49 \text { to } 72 \\
73 \text { to } 93\end{array}$ & \multirow{2}{*}{$\begin{array}{l}\text { units } \\
\text { I.M. } \\
600,000 \\
1,200,000 \\
900,000 \\
000,000 \\
\text { P.O. } \\
250,000 \\
000,000\end{array}$} & $\begin{array}{c}m l . \\
8,335 \\
8,920 \\
9,580 \\
3,575\end{array}$ & $\begin{array}{c}m l . \\
4,740 \\
5,320 \\
5,200 \\
5,930\end{array}$ & $\begin{array}{c}\text { units } \\
376,000 \\
847,350 \\
692,000 \\
79,900\end{array}$ & \multirow[t]{2}{*}{$\begin{array}{l}62.7 \\
70.6 \\
76.8\end{array}$} & \multirow{2}{*}{$\begin{array}{l}62.7 \\
68.0 \\
70.9 \\
73.9 \\
\\
68.5 \\
68.8\end{array}$} \\
\hline $\begin{array}{r}94 \text { to } 117 \\
118 \text { to } 132\end{array}$ & & $\begin{array}{l}7,855 \\
2,500\end{array}$ & $\begin{array}{l}7,240 \\
2,470\end{array}$ & $\begin{array}{l}24,320 \\
13,510\end{array}$ & & \\
\hline \multicolumn{7}{|c|}{ Subject-S } \\
\hline $\begin{array}{c}\text { hours } \\
0 \text { to } 24 \\
25 \text { to } 48 \\
49 \text { to } 72 \\
73 \text { to } 93\end{array}$ & \multirow{2}{*}{$\begin{array}{l}\text { units } \\
\text { I.M. } \\
600,000 \\
1,200,000 \\
900,000 \\
000,000 \\
\text { P.O. } \\
250,000 \\
000,000\end{array}$} & $\begin{array}{c}m l . \\
9,195 \\
4,920 \\
7,250 \\
3,015\end{array}$ & $\begin{array}{c}m l . \\
5,115 \\
3,055 \\
1,525 \\
3,225\end{array}$ & $\begin{array}{c}\text { units } \\
453,000 \\
631,300 \\
244,500 \\
185,250\end{array}$ & \multirow[t]{2}{*}{$\begin{array}{l}75.5 \\
52.6 \\
27.1\end{array}$} & \multirow{2}{*}{$\begin{array}{l}75.5 \\
60.2 \\
49.2 \\
56.0 \\
\\
52.4 \\
52.9\end{array}$} \\
\hline $\begin{array}{r}94 \text { to } 117 \\
118 \text { to } 132\end{array}$ & & $\begin{array}{l}3,215 \\
1,000\end{array}$ & $\begin{array}{r}4,640 \\
990\end{array}$ & $\begin{array}{l}31,800 \\
13,100\end{array}$ & & \\
\hline \multicolumn{7}{|c|}{ Subject-W } \\
\hline & \multirow{3}{*}{$\begin{array}{c}\text { units } \\
\text { I.M. } \\
600,000 \\
1,200,000 \\
900,000 \\
000,000 \\
\text { P.O. } \\
250,000 \\
000,000\end{array}$} & $m l$. & & & \multirow{3}{*}{$\begin{array}{l}45.5 \\
55.2 \\
28.8\end{array}$} & \multirow{3}{*}{$\begin{array}{l}45.5 \\
51.9 \\
44.3 \\
46.4 \\
42.6 \\
42.6\end{array}$} \\
\hline $\begin{array}{r}0 \text { to } 24 \\
25 \text { to } 48 \\
49 \text { to } 72 \\
73 \text { to } 93\end{array}$ & & $\begin{array}{l}5,320 \\
9,220 \\
8,060 \\
4,015\end{array}$ & $\begin{array}{l}3,455 \\
3,940 \\
3,050 \\
3,625\end{array}$ & $\begin{array}{r}273,350 \\
662,000 \\
259,650 \\
57,500\end{array}$ & & \\
\hline $\begin{array}{r}94 \text { to } 117 \\
118 \text { to } 132\end{array}$ & & $\begin{array}{l}4,875 \\
2,000\end{array}$ & $\begin{array}{l}4,760 \\
1,140\end{array}$ & $\begin{array}{l}6,000 \\
1,225\end{array}$ & & \\
\hline
\end{tabular}

* A total of $2,950,000$ units were administered to each subject, the first $2,700,000$ intramuscularly and the last 250,000 by mouth. 
STREPTOMYCIN IN HUMAN CHRONIC TYPHOID CARRIERS

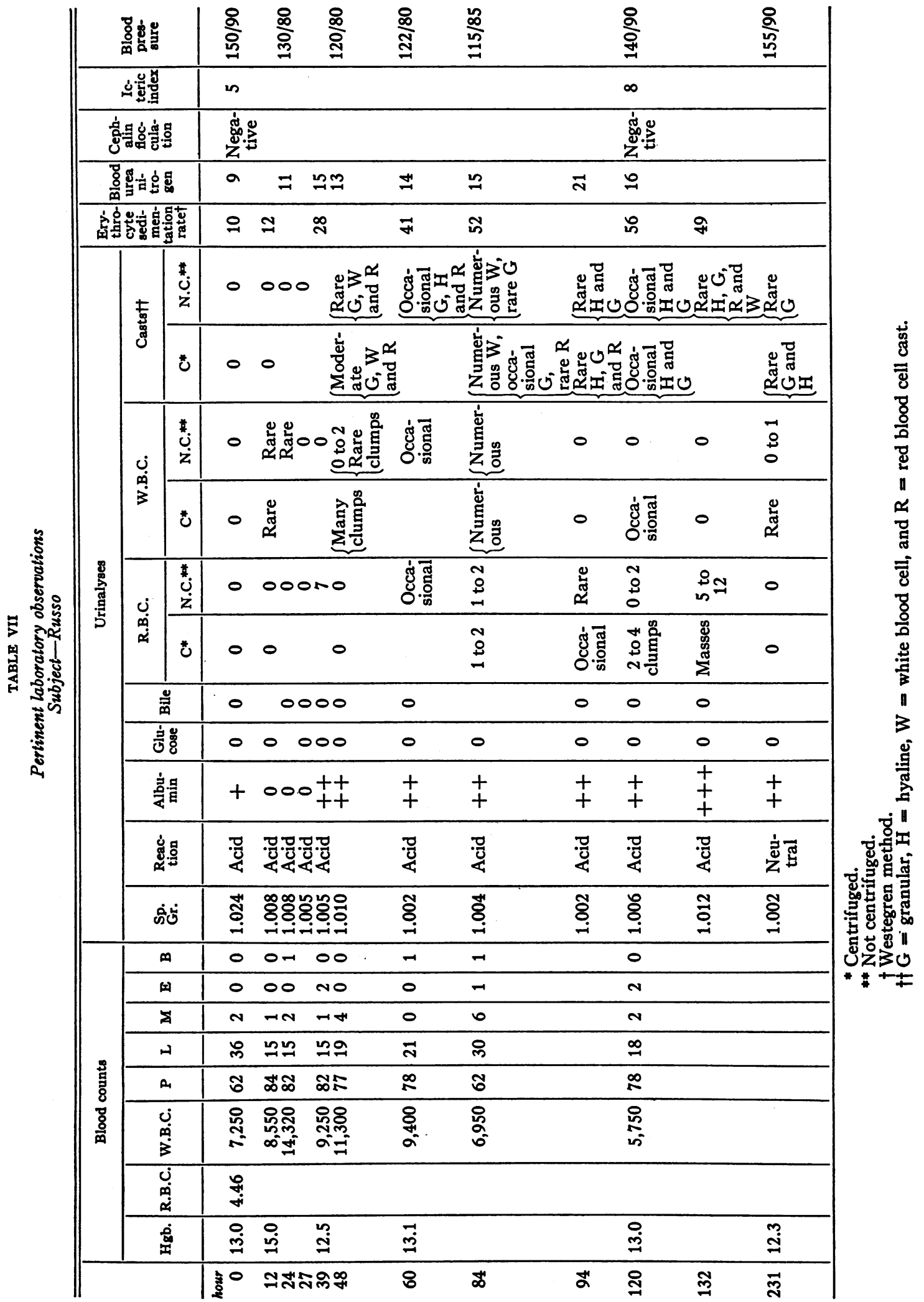




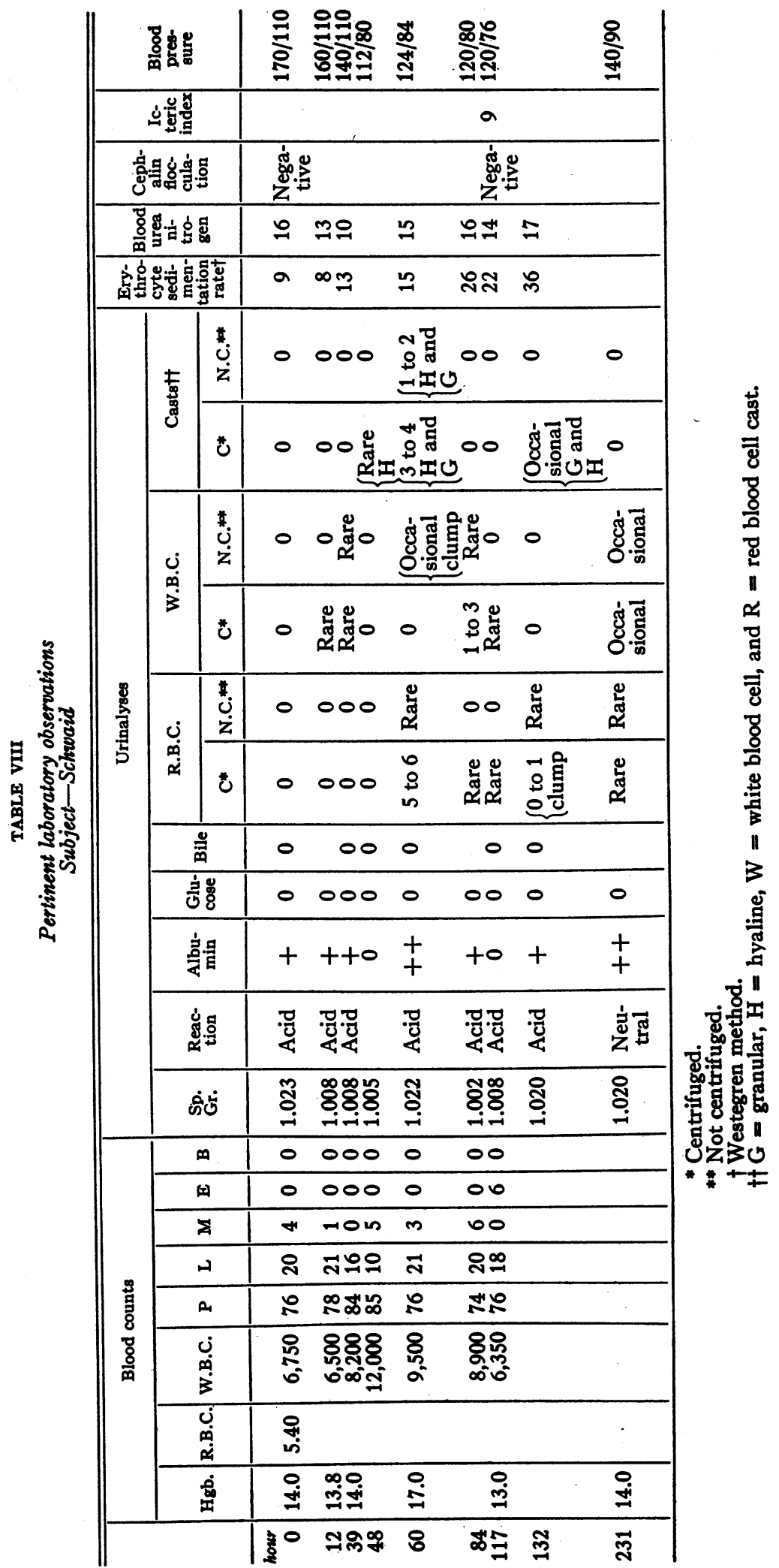




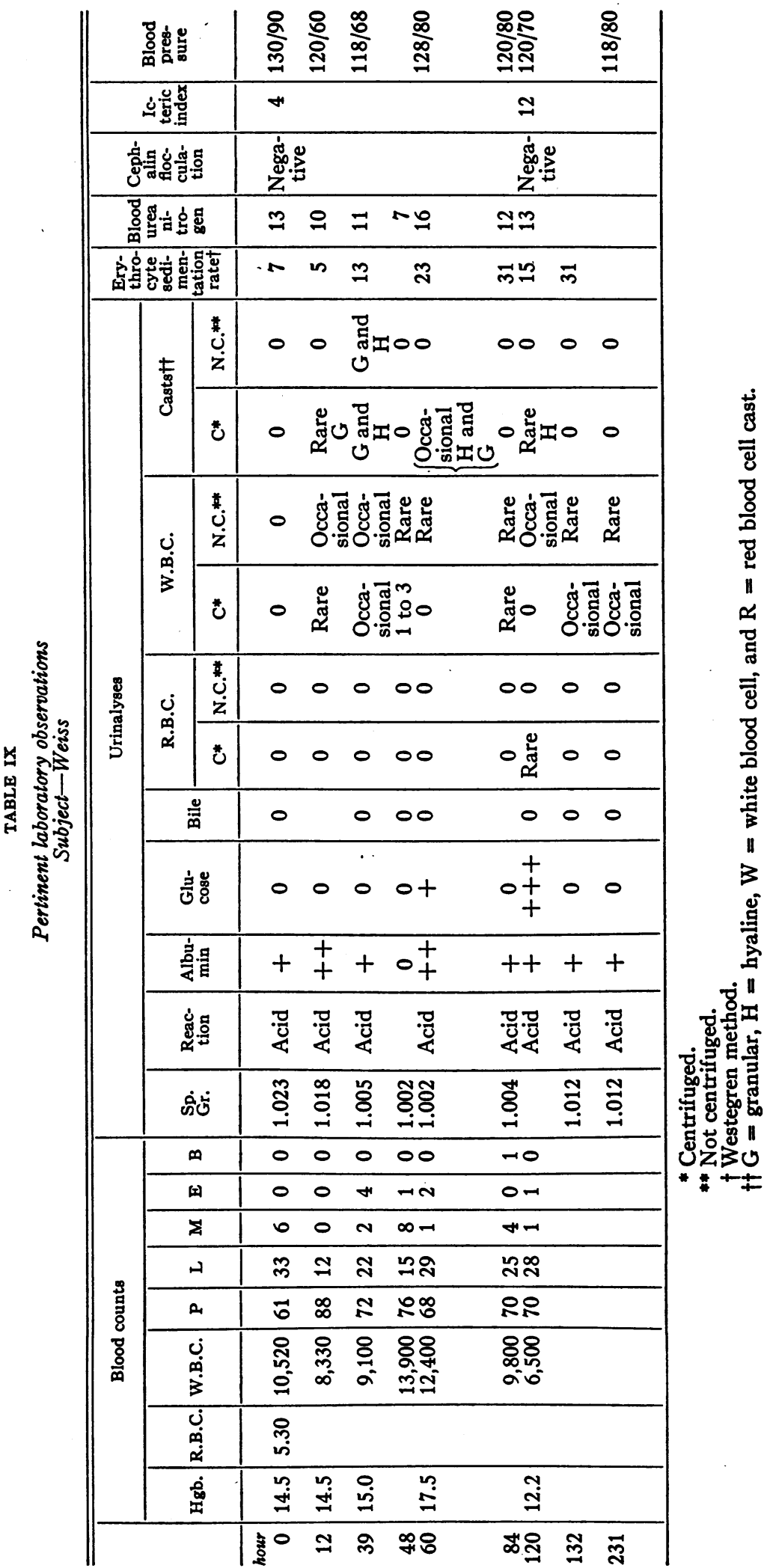


mately 4 days following the completion of the experiment at the two hundred thirty-first hour showed a decrease in the abnormal findings in the urine.

The patients also developed fever and signs of inflammation at the sites of injection. From more recent experience in the use of this drug (16) the toxic manifestations demonstrated by the 2 lots of drugs studied would be considered atypical and have not resulted from therapy with subsequent lots of streptomycin. The only change noted in the cardiovascular system was a depression in the systolic and diastolic blood pressure which became manifest very early in the course of drug administration as indicated by the blood pressure measurements at the twelfth hour in Tables VI to VIII. The daily electrocardiograms showed no significant changes.

The data in 2 recent publications $(17,18)$, utilizing the same method of assay described in this paper, could not be compared with these results since the minimum period for which data were presented in those studies was 24 hours.

\section{Typhoid carrier study}

The stool cultures taken prior to the administration of the drug were all strongly positive for $B$. typhosus. The typhoid bacilli isolated from patient $R$ proved to be type $E$, and that from patient $W$, type $A$. The typhoid bacilli isolated from the other 2 patients did not type. The sensitivity of the typhoid bacilli to streptomycin ranged between 10 and 20 units per ml. $(S=10$ units per ml.; $\mathrm{N}, \mathrm{R}$, and $\mathrm{W}=20$ units per ml.).

There were no significant changes in the number of typhoid bacilli in the stools of any of the patients during the intramuscular administration of the drug. Stool specimens from 2 of 3 patients (from patient $\mathrm{S}$ and $\mathrm{W}$ but not from patient $\mathrm{R}$ ), obtained at the end of the 24-hour period of oral administration of 31,250 units of the drug every 3 hours, were negative for typhoid bacilli but were positive again 12 hours later.

The urine cultures were negative prior to therapy and remained so.

\section{SUMMARY AND CONCLUSIONS}

1. Absorption and excretion of streptomycin following intramuscular and oral administration were studied in 4 human typhoid carriers. Streptomycin was administered every 3 hours in a dosage of 75,000 and 150,000 units intramuscularly and 31,250 units orally.

2. Following intramuscular administration of streptomycin approximately 60 to 70 per cent of the drug was excreted in the urine during a 24hour period. Appreciable amounts of the drug were not absorbed from the gastrointestinal tract following repeated administration of capsules containing 31,250 units.

3. Blood concentrations of streptomycin following administration of 75,000 units intramuscularly every 3 hours ranged from 0 to 6 units per $\mathrm{ml}$. and when the dose was increased to 150,000 units every 3 hours, the level rose to 5 to 20 units per $\mathrm{ml}$.

4. Certain toxic manifestations unique for these particular lots of drug were noted.

5. At a dosage level of 75,000 or 150,000 units intramuscularly every 3 hours, no significant bacteriostatic effect on the typhoid bacilli in the stool was obtained. Following oral administration of 31,250 units every 3 hours, a definite transitory bacteriostatic effect on the typhoid bacilli in the stool was obtained in 2 of 3 patients.

The authors wish to express their appreciation to Dr. Harry J. Robinson for his most helpful assistance during the course of this study.

\section{BIBLIOGRAPHY}

1. Schatz, A., Bugie, E., and Waksman, S. A., Streptomycin, a substance exhibiting antibiotic activity against gram-positive and gram-negative bacteria. Proc. Soc. Exper. Biol. and Med., 1944, 55, 66.

2. Jones, D., Metzger, H. J., Schatz, A., and Waksman, S. A., Control of gram-negative bacteria in experimental animals by streptomycin. Science, 1944, 100, 103.

3. Robinson, H. J., Smith, D. G., and Graessle, O. E., Chemotherapeutic properties of streptomycin. Proc. Soc. Exper. Biol. and Med., 1944, 57, 226.

4. Heilman, F. R., Streptomycin in the treatment of experimental infections with micro-organisms of the Friedlander group (Klebsiella). Proc. Staff Meet., Mayo Clin., 1945, 20, 33.

5. Waksman, S. A., Bugie, E., and Schatz, A., Isolation of antibiotic substances from soil micro-organisms, with special reference to streptothricin and streptomycin. Proc. Staff Meet., Mayo Clin., 1944, 19, 537. 
6. Metzger, H. J., Waksman, S. A., and Pugh, L. H., In vivo activity of streptothricin against Brucella abortus. Proc. Soc. Exper. Biol. and Med., 1942, $51,251$.

7. Feldman, W. H., and Hinshaw, H. C., Effects of streptomycin on experimental tuberculosis in guinea pigs: a preliminary report. Proc. Staff Meet, Mayo Clin., 1944, 19, 593.

8. Heilman, F. R., Streptomycin in the treatment of experimental tularemia. Proc. Staff Meet., Mayo Clin., 1944, 19, 553.

9. Feldman, W. H., Hinshaw, H. C., and Mann, F. C., In press.

10. Cathcart, R. T., Spain, D. M., and Rutstein, D. D., Unpublished observations.

11. Conway, E. J., and O'Malley, E., Microdiffusion methods. Ammonia and urea using buffered absorbents (revised methods for ranges greater than ten micrograms N). Biochem. J., 1942, 36, 655.
12. Hanger, F. M., The flocculation of the cephalincholesterol emulsions by pathological sera. Tr. As. Am. Physicians, 1938, 53, 148.

13. Craigie, J., and Yen, C. H., The demonstration of types of B. typhosus by means of preparations of type II Vi Phage. Canad. J. Pub. Health, 1938, 29, 448 and 484.

14. Foster, J. W., and Woodruff, H. B., Quantitative estimation of streptothricin. J. Bact., 1943, 45, 408.

15. Stebbins, R. B., and Robinson, H. J., A method for determination of streptomycin in body fluids. Proc. Soc. Exper. Biol. and Med., 1945, 59, 255.

16. Robertson, D. F., Personal communication.

17. Elias, W. F., and Durso, J., Blood, urine, and fecal levels of streptomycin in the treatment of human infections of E. typhosa. Science, 1945, 101, 589.

18. Reimann, H. A., Elias, W. F., and Price, A. H., Streptomycin for typhoid. J. A. M. A., 1945, 128, 175 